Originalveröffentlichung in: Astrid Erll, Ansgar Nünning (Hg.), Cultural Memory Studies. An International and Interdisciplinary Handbook, Berlin, New York 2008, S. 109-118

\title{
Communicative and Cultural Memory
}

\author{
JAN ASSMANN
}

\section{Memory: Individual, Social, and Cultural}

Memory is the faculty that enables us to form an awareness of selfhood (identity), both on the personal and on the collective level. Identity, in its turn, is related to time. A human self is a "diachronic identity," built "of the stuff of time" (Luckmann). This synthesis of time and identity is effectuated by memory. For time, identity, and memory we may distinguish among three levels:

\begin{tabular}{|l|l|l|l|}
\hline Level & Time & Identity & Memory \\
\hline $\begin{array}{l}\text { inner (neuro- } \\
\text { mental) }\end{array}$ & $\begin{array}{l}\text { inner, } \\
\text { subjective } \\
\text { time }\end{array}$ & inner self & $\begin{array}{l}\text { individual } \\
\text { memory }\end{array}$ \\
\hline social & social time & $\begin{array}{l}\text { social self, } \\
\text { person as } \\
\text { carrier of } \\
\text { social roles }\end{array}$ & $\begin{array}{l}\text { communicative } \\
\text { memory }\end{array}$ \\
\hline cultural & $\begin{array}{l}\text { historical, } \\
\text { mythical, } \\
\text { cultural time }\end{array}$ & $\begin{array}{l}\text { identity } \\
\text { cultural } \\
\text { memory }\end{array}$ \\
\hline
\end{tabular}

Figure 1

On the inner level, memory is a matter of our neuro-mental system. This is our personal memory, the only form of memory that had been recognized as such until the 1920s. On the social level, memory is a matter of communication and social interaction. It was the great achievement of the French sociologist Maurice Halbwachs to show that our memory depends, like consciousness in general, on socialization and communication, and that memory can be analyzed as a function of our social life (Les cadres sociaux; La mémoire collective). Memory enables us to live in groups and communities, and living in groups and communities enables us to build a memory. During these same years, psychoanalysts such as Sigmund Freud and Carl Gustav Jung were developing theories of collective memory but still adhered to the first, the inner and personal level, looking for collective memory not in the dynamics of social life but in the unconscious depths of the human psyche (see also Straub, this volume). 
Aby Warburg, however, the art historian, coined the term "social memory" with regard to the third, the cultural level; he seems to have been the first one who treated images, that is, cultural objectivations, as carriers of memory. His main project was to study the "afterlife" (Nacbleben) of classical antiquity in Western culture and he termed this project "Mnemosyne," the ancient Greek term for memory and the mother of the nine Muses. As an art historian, Warburg specialized in what he called Bildgedächtnis (iconic memory), but the general approach to reception history as a form of (cultural) memory could be applied to every other domain of symbolic forms as well (Gombrich). This is what Thomas Mann endeavored to do in his four Joseph novels, which appeared between 1933 and 1943 and which may rank as the most advanced attempt to reconstruct a specific cultural memory-in this case of people living in Palestine and Egypt in the Late Bronze Age - and, at the same time, to conjure up our European cultural memory and its Jewish foundations in times of anti-Semitism (J. Assmann, Thomas Mann). Neither Warburg nor Thomas Mann, however, used the term "cultural memory"; this concept has been explicitly developed only during the last twenty years. It is, therefore, only since then that the connection between time, identity, and memory in their three dimensions of the personal, the social, and the cultural has become more and more evident.

The term "communicative memory" was introduced in order to delineate the difference between Halbwachs's concept of "collective memory" and our understanding of "cultural memory" (A. Assmann). Cultural memory is a form of collective memory, in the sense that it is shared by a number of people and that it conveys to these people a collective, that is, cultural, identity. Halbwachs, however, the inventor of the term "collective memory," was careful to keep his concept of collective memory apart from the realm of traditions, transmissions, and transferences which we propose to subsume under the term "cultural memory." We preserve Halbwachs's distinction by breaking up his concept of collective memory into "communicative" and "cultural memory," but we insist on including the cultural sphere, which he excluded, in the study of memory. We are, therefore, not arguing for replacing his idea of "collective memory" with "cultural memory"; rather, we distinguish between both forms as two different modi memorandi, ways of remembering.

\section{Culture as Memory}

Cultural memory is a kind of institution. It is exteriorized, objectified, and stored away in symbolic forms that, unlike the sounds of words or the 
sight of gestures, are stable and situation-transcendent: They may be transferred from one situation to another and transmitted from one generation to another. External objects as carriers of memory play a role already on the level of personal memory. Our memory, which we possess as beings equipped with a human mind, exists only in constant interaction not only with other human memories but also with "things," outward symbols. With respect to things such as Marcel Proust's famous madeleine, or artifacts, objects, anniversaries, feasts, icons, symbols, or landscapes, the term "memory" is not a metaphor but a metonym based on material contact between a remembering mind and a reminding object. Things do not "have" a memory of their own, but they may remind us, may trigger our memory, because they carry memories which we have invested into them, things such as dishes, feasts, rites, images, stories and other texts, landscapes, and other "lieux de mémoire." On the social level, with respect to groups and societies, the role of external symbols becomes even more important, because groups which, of course, do not "have" a memory tend to "make" themselves one by means of things meant as reminders such as monuments, museums, libraries, archives, and other mnemonic institutions. This is what we call cultural memory (A. Assmann). In order to be able to be reembodied in the sequence of generations, cultural memory, unlike communicative memory, exists also in disembodied form and requires institutions of preservation and reembodiment.

This institutional character does not apply to what Halbwachs called collective memory and what we propose to rename communicative memory. Communicative memory is non-institutional; it is not supported by any institutions of learning, transmission, and interpretation; it is not cultivated by specialists and is not summoned or celebrated on special occasions; it is not formalized and stabilized by any forms of material symbolization; it lives in everyday interaction and communication and, for this very reason, has only a limited time depth which normally reaches no farther back than eighty years, the time span of three interacting generations. Still, there are frames, "communicative genres," traditions of communication and thematization and, above all, the affective ties that bind together families, groups, and generations.

A change of frames brings about forgetting; the durability of memories depends on the durability of social bonds and frames. In his earlier work, Halbwachs does not seem to be concerned with the social interests and power structures that are active in shaping and framing individual memories. In his last work on collective memory, however, he shows a keen awareness of institution and power. La topographie légendaire des évangiles en terre sainte, published in 1941 during the German occupation, deals with the transformation of Palestine into a site of Christian memory by the 
installment of all kinds of memorials, a process which took place after the adoption of Christianity as the state religion by the Roman empire. In this work, he crosses the border which he himself had erected between mémoire and tradition and shows to what degree this kind of official memory is dependent on theological dogma and formed by the power structure of the church.

\section{Time Frames}

Jan Vansina, an anthropologist who worked with oral societies in Africa, devoted an important study to the form in which they represent the past and observed a tripartite structure. The recent past, which looms large in interactive communication, recedes, as time goes by, more and more into the background. Information becomes scarcer and vaguer the further back one moves into the past. According to Vansina, this knowledge of affairs that are told and discussed in everyday communication has a limited depth in time, reaching not beyond three generations. Concerning a more remote past, there is either a total lack of information or one or two names are produced with great hesitation. For the most remote past, however, there is again a profusion of information dealing with traditions about the origin of the world and the early history of the tribe. This information, however, is not committed to everyday communication but intensely formalized and institutionalized. It exists in the forms of narratives, songs, dances, rituals, masks, and symbols; specialists such as narrators, bards, mask-carvers, and others are organized in guilds and have to undergo long periods of initiation, instruction, and examination. Moreover, it requires for its actualization certain occasions when the community comes together for a celebration. This is what we propose calling "cultural memory." In oral societies, as Vansina has shown, there is a gap between the informal generational memory referring to the recent past and the formal cultural memory which refers to the remote past, the origin of the world, and the history of the tribe, and since this gap shifts with the succession of generations, Vansina calls it the "floating gap." Historical consciousness, Vansina resumes, operates in oral societies on only two levels: the time of origins and the recent past.

Vansina's "floating gap" illustrates the difference between social and cultural frames of memory or communicative and cultural memory. The communicative memory contains memories referring to Vansina's "recent past." These are the memories that an individual shares with his contemporaries. This is what Halbwachs understood by "collective memory" and what forms the object of oral history, that branch of historical research 
that bases itself not on the usual written sources of historiography, but exclusively on memories gained in oral interviews. All studies in oral history confirm that even in literate societies living memory goes no further back than eighty years after which, separated by the floating gap, come, instead of myths of origin, the dates from schoolbooks and monuments.

The cultural memory is based on fixed points in the past. Even in the cultural memory, the past is not preserved as such but is cast in symbols as they are represented in oral myths or in writings, performed in feasts, and as they are continually illuminating a changing present. In the context of cultural memory, the distinction between myth and history vanishes. Not the past as such, as it is investigated and reconstructed by archaeologists and historians, counts for the cultural memory, but only the past as it is remembered. Here, in the context of cultural memory, it is the temporal horizon of cultural memory which is important. Cultural memory reaches back into the past only so far as the past can be reclaimed as "ours." This is why we refer to this form of historical consciousness as "memory" and not just as knowledge about the past. Knowledge about the past acquires the properties and functions of memory if it is related to a concept of identity. While knowledge has no form and is endlessly progressive, memory involves forgetting. It is only by forgetting what lies outside the horizon of the relevant that it performs an identity function. Nietzsche (The Use and Abuse of History) circumscribed this function by notions such as "plastic power" and "horizon," obviously intending the same thing for which now the term "identity" has become generally accepted.

Whereas knowledge has a universalist perspective, a tendency towards generalization and standardization, memory, even cultural memory, is local, egocentric, and specific to a group and its values.

\section{Identity}

The distinction of different forms of memory looks like a structure but it works more as a dynamic, creating tension and transition between the various poles. There is also much overlapping. This holds true especially with respect to the relation between memory and identity. We must certainly avoid falling victim to what Amartya Sen has described as the "identity illusion." Individuals possess various identities according to the various groups, communities, belief systems, political systems, etc. to which they belong, and equally multifarious are their communicative and cultural, in short: collective memories. On all levels, memory is an open system. Still, it is not totally open and diffuse; there are always frames that relate memory to specific horizons of time and identity on the individual, 
generational, political, and cultural levels. Where this relation is absent, we are not dealing with memory but with knowledge. Memory is knowledge with an identity-index, it is knowledge about oneself, that is, one's own diachronic identity, be it as an individual or as a member of a family, a generation, a community, a nation, or a cultural and religious tradition.

Groups are formed and cohere by the dynamics of association and dissociation which is always loaded (to varying degrees) with affection. Halbwachs, therefore, spoke of "communautés affectives." These "affective ties" lend memories their special intensity. Remembering is a realization of belonging, even a social obligation. One has to remember in order to belong: This is also one of the most important insights in Nietzsche's Genealogy of Morality. Assimilation, the transition of one group into another one, is usually accompanied by an imperative to forget the memories connected with the original identity. Inversely, this kind of assimilatory forgetting is precisely what is most feared and prohibited in the book of Deuteronomy, which deals with such a change of frame between Egypt and Canaan and the first and second generations of emigrants from Egypt.

\section{Institutions and Carriers}

The difference between communicative and cultural memory expresses itself also in the social dimension, in the structure of participation. The participation of a group in communicative memory is diffuse. Some, it is true, know more, some less, and the memories of the old reach farther back than those of the young. However, there are no specialists of informal, communicative memory. The knowledge which is communicated in everyday interaction has been acquired by the participants along with language and social competence. The participation of a group in cultural memory, by contrast, is always highly differentiated. This applies even and especially to oral and egalitarian societies. The preservation of the cultural memory of the group was originally the task of the poets. Even today, the African griots fulfill this function of guardians of cultural memory.

The cultural memory always has its specialists, both in oral and in literate societies. These include shamans, bards, and griots, as well as priests, teachers, artists, clerks, scholars, mandarins, rabbis, mullahs, and other names for specialized carriers of memory. In oral societies, the degree of specialization of these carriers depends on the magnitude of the demands that are made of their memory. Those demands that insist on verbatim transmission are ranked highest. Here, human memory is used as a "database" in a sense approaching the use of writing: A fixed text is verbally 
"written" into the highly specialized and trained memory of these specialists. This is typically the case when ritual knowledge is at stake and where a ritual must strictly follow a "script," even if this script is not laid down in writing. The Rgveda constitutes the most prominent example of a codification of ritual memory based solely on oral tradition. The magnitude of this task corresponds to the social rank of the ritual specialists, the Brahmin, who form the highest caste, higher even than the aristocratic class of warriors (Kshatriya) to which the rulers belong. In traditional Rwanda, the scripts for the eighteen royal rituals had to be memorized by specialists who ranked as the highest notables of the kingdom. Error could be punished by death. Those three notables who knew by heart the full text of all eighteen rituals even partook of the divinity of the ruler (Borgeaud).

In the context of rituals, therefore, we observe the rise of the oldest systems of memorization or mnemotechniques, with or without the help of systems of notation like knotted chords, tchuringas, and other forms of pre-writing. With the invention of full-fledged systems of writing, it is interesting to see how differently various religions have behaved vis à vis this new cultural technique. In the Indo-European traditions, from the Indian Brahmins to the Celtic Druids, we observe a general distrust and shunning of writing. Memory is held to be by far the more trustworthy medium to hand down the religious (that is, ritual) knowledge to later generations. The reason normally given is that too many mistakes may creep into a text by copying. The true reason, however, seems to be that writing always implies the danger of dissemination, of giving away a secret tradition to the profane and uninitiated. This distrust in writing is still very prominent in Plato. In the ancient Near Eastern societies such as Mesopotamia, Israel, and Egypt, on the other hand, writing is eagerly grasped as an ideal medium for codifying and transmitting the sacred traditions, especially ritual scripts and recitations.

But even where the sacred tradition is committed to writing, memorization plays the central role. In ancient Egypt, a typical temple library contained no more books than may be known by heart by the specialists. Clement of Alexandria gives a vivid description of such a library. $\mathrm{He}$ speaks of forty-two "indispensable" or "absolutely necessary" (pany anankaiai) books that formed the stock of an Egyptian temple library and were all written by Thot-Hermes himself. The priests were not supposed to read and learn all of the books, but to specialize in certain genres corresponding to their rank and office. In describing a procession of these priests, Clement shows both the hierarchy of the priesthood and the structure of their library (Stromateis 6.4.35-37). The highest ranks are held by the stolistes and the prophetes, corresponding in Egyptian terminology to the "lector priest" and the "high priest." It is the books of the stolist that 
serve as a codification of ritual memory proper, complemented by what Clement calls "education." The books of the high priest, on the other hand, are said to contain normative or legal literature concerning the laws, the gods, and priestly education. The library, thus, is divided into normative knowledge, which ranks highest; ritual knowledge, which comes a close second; and general knowledge concerning astronomy, geography, poetry, biography, and medicine, which occupies the lowest rank among this canon of highly indispensable literature.

There is, however, still another sense in which the participation in cultural memory may be structured in a society. This concerns the question of restricted knowledge, of secrecy and esotericism. Every traditional society knows areas of restricted knowledge whose boundaries are not simply defined by the different capacities of human memory and understanding, but also by questions of access and initiation. In Judaism, for example, general participation is required in the Torah which every (male) member of the group is supposed to know by heart. Specialized participation concerns the world of Talmudic and Medieval commentaries, codices, and midrash, a vast body of literature that only specialists can master. Secrecy, however, shrouds the esoteric world of kabbala, to which only select adepts (and only after they have reached the age of forty) are admitted.

The participation structure of cultural memory has an inherent tendency to elitism; it is never strictly egalitarian. Some are almost forced into participation and have to prove their degree of admittance by formal exams (as in traditional China); or by the mastery of linguistic registers (as in England); or of the "Citatenschatz des deutschen Volkes" (treasury of German quotations) as in nineteenth-century Germany. Others remain systematically excluded from this "distinguished" knowledge, such as women in ancient Greece, traditional China, and orthodox Judaism, or the lower classes in the heyday of the German Bildungsbirigertum (educated bourgeoisie).

As to the media of cultural memory, a more or less pronounced tendency can be discerned towards a form of intra-cultural diglossia, corresponding to the distinction between one "great tradition" and several "little traditions" as proposed by Robert Redfield. Until the creation of modern Iwrith, the Jews had always lived in a situation of diglossia, since their "Great Tradition" was written in Hebrew and for their everyday communication they used vernacular languages such as Yiddish, Ladino, or the various languages of their host countries. To a similar or lesser degree, this situation is typical of virtually all traditional societies, be it in the form of two different languages, such as Hindu and Sanskrit or Italian and Latin, or two different linguistic varieties, such as Qur'anic and vernacular Arabic or classical and modern Chinese. Modern societies tend to 
diversify this binary structure by introducing more linguistic varieties according to the multiplication of cultural media such as film, broadcasting, and television. The following list with its clear-cut binary structure, therefore, does not do full justice to the modern situation:

\begin{tabular}{|c|c|c|}
\hline & $\begin{array}{l}\text { Communicative } \\
\text { Memory }\end{array}$ & Cultural Memory \\
\hline Content & $\begin{array}{l}\text { history in the frame of } \\
\text { autobiographical memory, } \\
\text { recent past }\end{array}$ & $\begin{array}{l}\text { mythical history, } \\
\text { events in absolute } \\
\text { past ("in illo } \\
\text { tempore") }\end{array}$ \\
\hline Forms & $\begin{array}{l}\text { informal traditions and } \\
\text { genres of everyday } \\
\text { communication }\end{array}$ & $\begin{array}{l}\text { high degree of } \\
\text { formation, } \\
\text { ceremonial } \\
\text { communication; }\end{array}$ \\
\hline Media & $\begin{array}{l}\text { living, embodied memory, } \\
\text { communication in } \\
\text { vernacular language }\end{array}$ & $\begin{array}{l}\text { mediated in texts, } \\
\text { icons, dances, rituals, } \\
\text { and performances of } \\
\text { various kinds; } \\
\text { "classical" or oth- } \\
\text { erwise formalized } \\
\text { language(s) }\end{array}$ \\
\hline $\begin{array}{l}\text { Time } \\
\text { Structure }\end{array}$ & $\begin{array}{l}80-100 \text { years, a moving } \\
\text { horizon of } 3-4 \text { interacting } \\
\text { generations }\end{array}$ & $\begin{array}{l}\text { absolute past, } \\
\text { mythical primordial } \\
\text { time, " } 3000 \text { years" }\end{array}$ \\
\hline $\begin{array}{l}\text { Participation } \\
\text { Structure }\end{array}$ & diffuse & $\begin{array}{l}\text { specialized carriers of } \\
\text { memory, } \\
\text { hierarchically } \\
\text { structured }\end{array}$ \\
\hline
\end{tabular}

Figure 2

Transitions and transformations account for the dynamics of cultural memory. Two typical directions have a structural significance and should at least briefly be mentioned in this context. One concerns the transition from autobiographical and communicative memory into cultural memory, and the other concerns, within cultural memory, the move from the rear stage to the forefront, from the periphery into the center, from latency or potentiality to manifestation or actualization and vice versa. These shifts presuppose structural boundaries which are to be crossed: the boundary between embodied and mediated forms of memory, and the boundary 
between what we propose calling "working" and "reference memories" or "canon" and "archive" (see also A. Assmann, this volume).

\section{References}

Assmann, Aleida. "Memory, Individual and Collective." The Oxford Handbook of Contextual Political Analysis. Eds. Robert E. Goodin und Charles Tilly. Oxford: Oxford UP, 2006. 210-24.

Assmann, Jan. "Das kulturelle Gedächtnis." Erwägen, Wissen, Ethik 13 (2002): 239-47.

—. Das kulturelle Gedächtnis: Schrift, Erinnerung und politische Identität in früben Hocbkulturen. Beck: Munich, 1992.

-. Thomas Mann und Ägyten: Mythos und Monotheismus in den Josephsromanen. Munich: Beck, 2006.

Borgeaud, Philippe. "Pour une approche anthropologique de la mémoire religieuse." La mémoire des religions. Eds. Jean-Claude Basset and Philippe Borgeaud. Geneva: Labor et Fides, 1988. 7-20.

Clemens von Alexandria. Stromateis. Trans. Otto Stählin. 3 vols. Munich: Kösel \& Pustet, 1936-38.

Gombrich, Ernst H. Aby Warburg: An Intellectual Biography. Chicago: U of Chicago P, 1986.

Halbwachs, Maurice. Les cadres sociaux de la mémoire. 1925. Paris: Albin Michel, 1994.

-. On Collective Memory. 1925. Ed. and trans. Lewis A. Coser. Chicago: U of Chicago P, 1992.

—. La mémoire collective. 1950. Paris: Albin Michel, 1997.

—. La topographie légendaire des évangiles en terre sainte. 1941. Paris: Presses universitaires de France, 1971.

Luckmann, Thomas. "Remarks on Personal Identity: Inner, Social and Historical Time." Identity: Personal and Socio-Cultural. Ed. Anita Jacobson-Widding. Atlantic Highlands, NJ: Humanities, 1983. 67-91.

Nietzsche, Friedrich. On the Genealogy of Morality. Trans. Maudemarie Clark and Alan J. Swensen. Indianapolis: Hackett, 1998.

-. The Use and Abuse of History. Trans. Adrian Collins. New York: Macmillan, 1957.

Redfield, Robert. Peasant Society and Culture: An Antbropological Approach to Civilization. Chicago: U of Chicago P, 1956.

Sen, Amartya. Identity and Violence: The Illusion of Destiny. New York: Norton, 2006.

Vansina, Jan. Oral Tradition as History. Madison: U of Wisconsin P, 1985.

Welzer, Harald. Das kommunikative Gedächtnis. Munich: Beck, 2002. 